\title{
Phages in Food Industry Biocontrol and Bioremediation
}

\author{
Pablo Cristobal-Cueto ${ }^{1}$, Alberto García-Quintanilla ${ }^{2} \mathbb{(}$, Jaime Esteban ${ }^{1}\left(\mathbb{D}\right.$ and Meritxell García-Quintanilla ${ }^{1, *}$ \\ 1 Department of Clinical Microbiology, IIS-Fundación Jiménez Díaz, Av. Reyes Católicos, 2, \\ 28040 Madrid, Spain; pablourjc09@gmail.com (P.C.-C.); jesteban@fjd.es (J.E.) \\ 2 Department of Biochemistry and Molecular Biology, School of Pharmacy, University of Seville, Calle Profesor \\ García Gonzalez, 2, 41012 Seville, Spain; albertgq1970@us.es \\ * Correspondence: meritxell.dejesus@fjd.es
}

Citation: Cristobal-Cueto, P.; García-Quintanilla, A.; Esteban, J.; García-Quintanilla, M. Phages in Food Industry Biocontrol and Bioremediation. Antibiotics 2021, 10, 786. https://doi.org/10.3390/ antibiotics 10070786

Academic Editor: Pilar García Suárez

Received: 30 May 2021

Accepted: 25 June 2021

Published: 28 June 2021

Publisher's Note: MDPI stays neutral with regard to jurisdictional claims in published maps and institutional affiliations.

Copyright: (c) 2021 by the authors. Licensee MDPI, Basel, Switzerland. This article is an open access article distributed under the terms and conditions of the Creative Commons Attribution (CC BY) license (https:/ / creativecommons.org/licenses/by/ $4.0 /)$.

\begin{abstract}
Bacteriophages are ubiquitous in nature and their use is a current promising alternative in biological control. Multidrug resistant (MDR) bacterial strains are present in the livestock industry and phages are attractive candidates to eliminate them and their biofilms. This alternative therapy also reduces the non-desirable effects produced by chemicals on food. The World Health Organization (WHO) estimates that around 420,000 people die due to a foodborne illness annually, suggesting that an improvement in food biocontrol is desirable. This review summarizes relevant studies of phage use in biocontrol focusing on treatments in live animals, plants, surfaces, foods, wastewaters and bioremediation.
\end{abstract}

Keywords: bacteriophage; food industry; bioremediation; biocontrol; animal; plant; surface

\section{Introduction}

The World Health Organization (WHO) estimates that around 420,000 people die every year due to a foodborne illness. This has an economic impact of US\$110 billionon the global economy. Furthermore, according to the $\mathrm{WHO}$, approximately $18 \%$ of the infectious disease outbreaks are related to the water in Europe [1], and this percentage may be higher in other continents. On the other hand, multidrug resistant (MDR) bacteria are a big concern not only in human health, but also in livestock industries. The global estimation of antimicrobial consumption (mg) per population correction unit (PCU) reported for cattle, chickens and pig is $45 \mathrm{mg} / \mathrm{PCU}, 148 \mathrm{mg} / \mathrm{PCU}$ and $172 \mathrm{mg} / \mathrm{PCU}$, respectively, and a rise of antimicrobials in food animal production has been projected by 67\% from 2010 to 2030, reaching 105,596 ( \pm 3605$)$ tons of antimicrobials by 2030 [2]. In this sense, China consumes the largest quantity of antimicrobials, followed by the United States of America, Brazil, Germany and India [2]. Moreover, transmission of MDR bacteria from animals to humans has been described [3] and is subject of surveillance.

In the last decades, the use of bacteriophages has reappeared in Western countries as an alternative to chemicals treatments [4]. Bacteriophages are recognized as the most abundant biological agents on Earth, due to their ubiquitous presence in the environment. Phages, for short, are able to lyse MDR bacteria and reduce the non-desirable effects produced by chemicals on food. According to their life cycle, they can be classified as virulent phages (lytic phages) or temperate phages (lysogenic phages) [5]. Lytic phages use the genomic and biosynthetic machinery of the bacteria to produce their progeny, provoking the bacterial lysis and their consequent release. The phage-encoded endolysins are ultimately responsible to break down the bacterial peptidoglycan at the final stage of the cycle [6]. Conversely, lysogenic phages are capable of incorporating their nucleic acid into the genome of the host cell or just remain like a plasmid into the host cell during multiple bacterial generations. Therefore, only lytic phages are usually used in bioremediation or phage therapy. Bacteria can become resistant to phages by modifying their receptors, turning them inaccessible or non-complementary to the phage receptor binding protein [7]. 
Fortunately, these insensitive strains can be lysed using cocktails of phages instead of a single phage.

Phages in food industry can be applied at different stages [8]: directly on animals or plants to eliminate the probability of bacterial infection and disease, in food production plants to prevent bacterial biofilm formation, or directly on food to preserve the product. This review excludes in vitro experiments and summarizes selected in vivo findings of phage use in non-human biocontrol, focusing on the treatment of live animals and plants that are relevant in the food industry, as well as the raw food products, and the biofilm control on surfaces during their processing and manufacturing, ending with the bioremediation of the wastewaters generated (Figure 1).

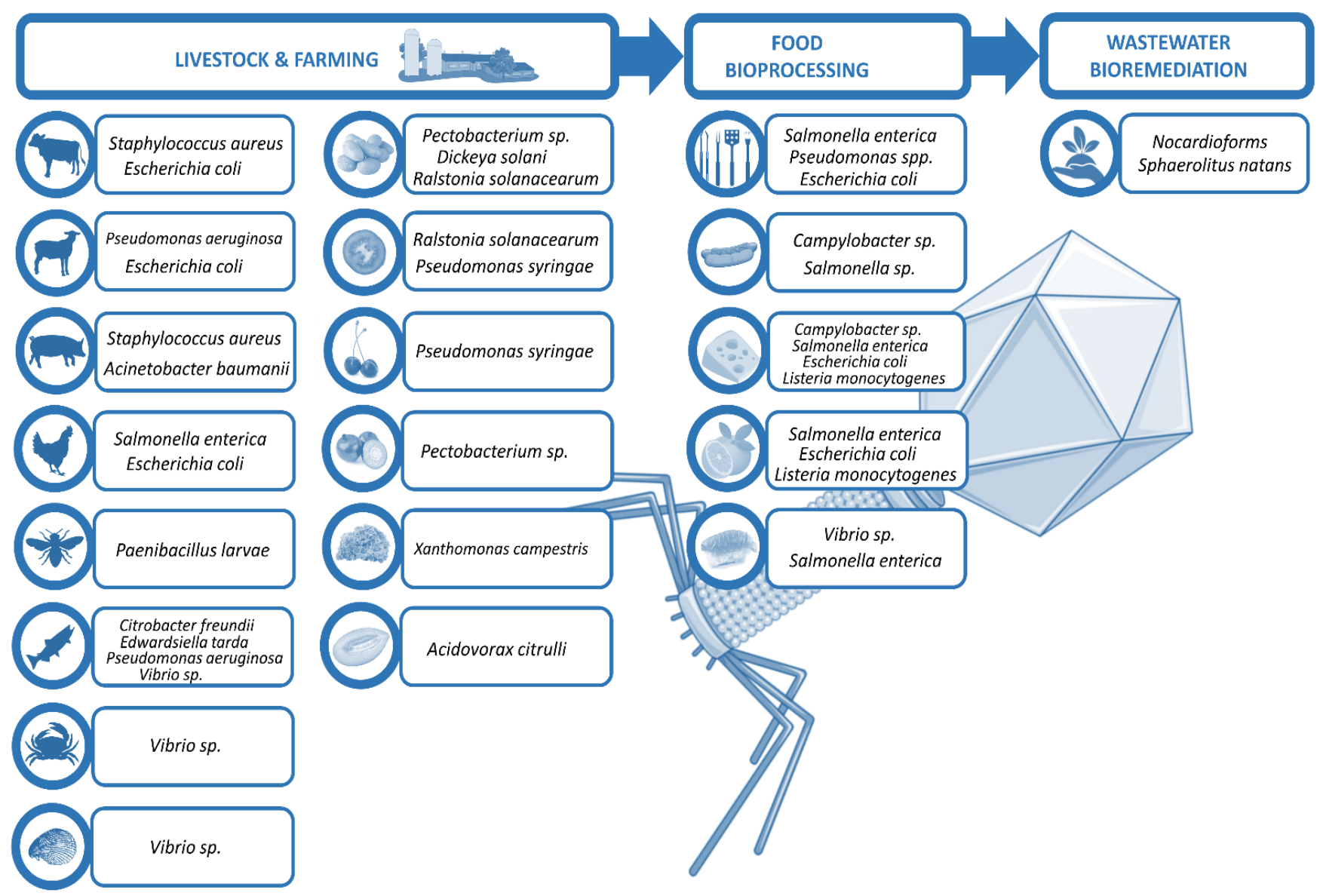

Figure 1. Scheme of phage utilities in biocontrol.

\section{Food and Phages}

According to the Centers for Disease, Control and Prevention (CDC) [9], foodborne infections produced by chicken, beef, pork and turkey are associated with Campylobacter and Salmonella presence meanwhile dairy products like raw milk and cheese are commonly infected by Campylobacter, Salmonella, Escherichia and Listeria. Most common bacteria infecting vegetables and fruits are Salmonella, Escherichia and Listeria and most frequent pathogen producing foodborne illnesses in fishes and shellfishes are Vibrio and Salmonella.

\subsection{Bacteriophages to Control Salmonella enterica}

One in three foodborne outbreaks in the European Union in 2018 were caused by Salmonella, being salmonellosis the second most commonly reported gastrointestinal infection in humans $(91,857$ cases reported) after campylobacteriosis $(246,571)$ [10].

Thung et al. studied the interaction of the bacteriophage SE07, isolated from retail meat samples, against $S$. enterica serovar Enteritidis on different food matrices, such as 
fruit juice, fresh egg, beef and chicken meat. The reduction of the bacteria population in all of them was significant at $12 \mathrm{~h}(2.05 \log \mathrm{CFU} / \mathrm{mL}, 1.98 \log \mathrm{CFU} / \mathrm{mL}, 1.79 \log$ $\mathrm{CFU} / \mathrm{mL}$, and $1.83 \log \mathrm{CFU} / \mathrm{mL}$, respectively), and after that time there was no further significant reduction [11]. In 2018, Phongtang et al. evaluated the effect of P22 phage (ATCC 97541) against $S$. enterica serovar Typhimurium in milk. This phage showed an inhibitory effect of more than $3 \log \mathrm{UFC} / \mathrm{mL}$ reduction after $4 \mathrm{~h}$ [12]. Bao et al. tested two lytic phages, vB_SenM-PA13076 (PA13076) and vB_SenM-PC2184 (PC2184), in chicken breast, pasteurized milk and Chinese cabbage. Phages were isolated from chicken sewage and infected S. enterica serovar Enteritidis. PA13076 was able to infect 222 strains (71.4\%) and PC2184 infected 298 strains (95.8\%) out of 311 isolates tested. The two phages were rapidly inactivated at temperatures above $60^{\circ} \mathrm{C}$ (PA13076) or $70^{\circ} \mathrm{C}(\mathrm{PC} 2184)$. Interestingly, PA13076 reduced Salmonella population in chicken breast, pasteurized milk and Chinese cabbage by $2 \log , 2 \log$ and $2.5 \log \mathrm{UFC} / \mathrm{mL}$, respectively, whereas PC2184 reduced bacteria population in chicken breast, pasteurized milk and Chinese cabbage by $3 \log , 4 \log$ and $3.5 \log \mathrm{UFC} / \mathrm{mL}$, respectively [13].

The company Micreos Food Safety has developed the brand Phageguard S (Table 1) based on phages Felix-O1a and S16 against Salmonella enterica. This product is able to kill all Salmonella serovars including those that are resistant to antibiotics and the 20 most virulent Salmonella strains according to the United States Department of Agriculture (USDA). Phageguard S can reduce bacterial population by $1-3 \log \mathrm{CFU} / \mathrm{mL}$ without affecting taste, odor or texture of foods. It is effective from 0 to $35^{\circ} \mathrm{C}$ and its use is recommended as final treatment in spray or directly immersing food into the phage solution [14]. Yeh et al. reported that the combination of phages S16 and Felix-O1a reduced Salmonella on ground beef and pork by 1 and $0.8 \log$ CFU/g, respectively [15]. A recent study tested Phageguard $\mathrm{S}$ on lean pork, bacon and pork trims with good results. The product administration decreased Salmonella population by $0.8-1.7 \log \mathrm{CFU} / \mathrm{cm}^{2}$ or g using $5 \times 10^{7} \mathrm{PFU} / \mathrm{cm}^{2}$ or $\mathrm{g}$ of phages [16].

\subsection{Bacteriophages to Control Listeria monocytogenes}

L. monocytogenes is peculiar due to its ability of growing at refrigerated temperatures $\left(2-8{ }^{\circ} \mathrm{C}\right)$. Guenther et al. showed the effect of the lytic A511 phage to control L. monocytogenes in different ready to eat foods. In liquid samples as chocolate milk and mozzarella cheese brine, this phage was able to reduce the L. monocytogenes population below the detection limit, while in solid samples (hot dogs, sliced turkey meat, smoked salmon, seafood, sliced cabbage, and lettuce leaves) the reduction was above $5 \log$ units [17]. Another phage used to control L. monocytogenes in food products and food processing environments is P70, a phage known to have a broad host range infecting Listeria sp. serovars $1 / 2 a, 1 / 2 b, 1 / 2 c$, $4 \mathrm{a}, 4 \mathrm{c}, 4 \mathrm{~d}, 4 \mathrm{e}, 5,6 \mathrm{a}$ and $6 \mathrm{~b}$ with results over $62 \%$ of lysis [18].

Currently, there are two products based on phages approved in the US to be used in food industry against Listeria (Table 1). The United States Food and Drug Administration and the U.S. Department of Agriculture approved ListShield ${ }^{\mathrm{TM}}$ (Intralytix, Baltimore, MA, USA) as a food additive for ready-to-eat meat and poultry products, usually as a spraying or dipping suspension [19]. ListShield ${ }^{\mathrm{TM}}$ is a mixture of six lytic phages targeting L. monocytogenes that does not affect the organoleptic quality of foods and does not produce adverse effects on commensal microbiota [20]. Gutierrez et al. tested the product ListShield ${ }^{\mathrm{TM}}$ on Spanish dry-cured ham and the surfaces that are commonly used in food industry and obtained a $100 \%$ lysis of L. monocytogenes strains examined. In dry-cured ham, the reduction of bacterial population was of $3.5 \log$ units after 14 days of incubation at $4{ }^{\circ} \mathrm{C}$. Moreover, ListShield was effective in removing $72 \mathrm{~h}$ biofilms formed on stainless steel surfaces by most of the assayed strains after four hours of treatment at $12{ }^{\circ} \mathrm{C}$ [21]. A recent study also tested the effectiveness of ListShield ${ }^{\mathrm{TM}}$ in chicken breast. The phage treatment reduced the bacterial population $0.84 \log \mathrm{CFU} / \mathrm{mL}$ when it was applied alone and $2.04 \log \mathrm{CFU} / \mathrm{mL}$ in combination with UV-C treatment during storage for $72 \mathrm{~h}$ without significant differences in colour, $\mathrm{pH}$ or food quality [22]. 
Table 1. List of approved and commercially available bacteriophage products.

\begin{tabular}{|c|c|c|}
\hline Company & Phage Product & Pathogen \\
\hline \multirow{3}{*}{$\begin{array}{l}\text { Micreos Food Safety } \\
\text { (The Netherlands) }\end{array}$} & PhageGuard Listex & Listeria sp. \\
\hline & PhageGuard S & Salmonella enterica \\
\hline & PhageGuard E & Escherichia coli O157:H7 \\
\hline \multirow{4}{*}{$\begin{array}{l}\text { Intralytix } \\
\text { (USA) }\end{array}$} & ListShield & Listeria monocytogenes \\
\hline & SalmoFresh & Salmonella enterica \\
\hline & ShigaShield & Shigella sp. \\
\hline & EcoShield PX & Escherichia coli \\
\hline \multirow{2}{*}{$\begin{array}{l}\text { Arm \& Hammer } \\
\text { (USA) }\end{array}$} & Finalyse SAL & Salmonella enterica \\
\hline & Finalyse & Escherichia coli O157:H7 \\
\hline \multirow{2}{*}{$\begin{array}{l}\text { Omnilytics } \\
\text { (USA) }\end{array}$} & BacWash & Salmonella enterica, Escherichia coli O157:H7 \\
\hline & AgriPhage & Xanthomonas campestris, Pseudomonas syringae \\
\hline $\begin{array}{l}\text { APS Biocontrol Ltd. } \\
\text { (UK) }\end{array}$ & Biolyse-PB & Erwinia sp., Pectobacterium sp., Pseudomonas sp. \\
\hline \multirow{2}{*}{$\begin{array}{l}\text { Proteon Pharmaceuticals SA } \\
\text { (Poland) }\end{array}$} & Bafasal & Salmonella enterica \\
\hline & Bafador & Pseudomonas sp., Aeromonas sp. \\
\hline $\begin{array}{l}\text { FINK TEC GmbH } \\
\text { (Germany) }\end{array}$ & Secure Shield E1 & Escherichia coli \\
\hline \multirow{6}{*}{$\begin{array}{l}\text { Brimmedical } \\
\text { (Georgia) }\end{array}$} & PYO Phage & $\begin{array}{l}\text { Staphylococcus sp., Escherichia coli, Streptococcus sp., } \\
\text { Pseudomonas sp., Proteus sp. }\end{array}$ \\
\hline & Intesti Phage & $\begin{array}{c}\text { Shigella sp., Salmonella enterica, Staphylococcus sp., } \\
\text { Proteus sp., } \\
\text { Escherichia coli, Pseudomonas aeruginosa }\end{array}$ \\
\hline & SES Phage & $\begin{array}{l}\text { Staphylococcus sp., } \\
\text { Enteropathogenic serotypes of Escherichia coli, } \\
\text { Streptococcus sp. }\end{array}$ \\
\hline & EnkoPhagum & $\begin{array}{l}\text { Salmonella enterica, Shigella sp., } \\
\text { Enteropathogenic serotypes of Escherichia coli, } \\
\text { Staphylococcus sp. }\end{array}$ \\
\hline & Fersisi Phage & $\begin{array}{l}\text { Staphylococcus sp., } \\
\text { Streptococcus sp. }\end{array}$ \\
\hline & Mono-phage & $\begin{array}{l}\text { Staphylococcus sp., Escherichia coli, Streptococcus sp., } \\
\text { Enterococcus sp., Pseudomonas aeruginosa, Proteus sp. }\end{array}$ \\
\hline
\end{tabular}

The second formulation approved in the USA is LISTEX ${ }^{\mathrm{TM}}$ P100 (Micreos Food Safety, Wageningen, The Netherlands), a brand composed of bacteriophage P100 produced to control L. monocytogenes. This product has been shown to reduce at least 3.5 log units on soft cheese [23]. Soni et al. demonstrated its activity on fresh channel catfish fillets (L. monocytogenes reduction between 1.4 and $2.0 \log \mathrm{CFU} / \mathrm{g}$ at $4{ }^{\circ} \mathrm{C}, 10^{\circ} \mathrm{C}$, and $22{ }^{\circ} \mathrm{C}$ ) [24], raw salmon (bacterial reduction of 1.8, 2.5, and $3.5 \log \mathrm{CFU} / \mathrm{g}$ from initial bacterial loads of 2, 3, and $4.5 \log \mathrm{CFU} / \mathrm{g}$, respectively, at $4^{\circ}$ and $22^{\circ} \mathrm{C}$ ) [25], and on soft cheese (with initial bacterial reduction of $2-4 \log \mathrm{CFU} / \mathrm{cm}^{2}$ at $4{ }^{\circ} \mathrm{C}$, but subsequent bacterial regrowth reported) [26]. Also this bacteriophage has been tested to reduce L. monocytogenes biofilms on stainless steel coupon surfaces resulting in high elimination of biofilm mass in all L. monocytogenes strains tested [27]. In 2017, the effect of this product was tested in sushi. Promising results were obtained in assays with initial 6-log CFU/g of bacteria and 8-log $\mathrm{PFU} / \mathrm{g}$ of phage inoculation at $22{ }^{\circ} \mathrm{C}$; a maximum reduction of $4.44 \mathrm{log} \mathrm{CFU} / \mathrm{g}$ was achieved when the product was inoculated directly in sashimi samples, compared with the 
control group [28]. LISTEX ${ }^{\mathrm{TM}} \mathrm{P} 100$ has also been tested in soft cheeses achieving a reduction of more than $2 \log$ CFU/mL [29]. Recently, the effect of the phage P100 in combination with the antimicrobial peptide pediocin PA-1 and mild high hydrostatic pressure was evaluated as a new method to eradicate Listeria from milk. The combination decreased immediately the L. monocytogenes population, although in a few cases a regrowth during the storage process was encountered [30].

\subsection{Bacteriophages to Control Escherichia coli}

The presence of E. coli in fruits, vegetables or animal products is a signal of inadequate hygiene during the processing methods in food industry since this bacterium is an indicator of fecal contamination in food and drinking water [31]. E. coli infections are characterized by diarrheal illnesses produced mainly by two strains: Shiga toxin-producing E. coli (STEC) and enterotoxigenic E. coli (ETEC) [32]. The detection of food contaminated by bacteria is actually a crucial strategy to avoid a large number of infections. For this reason, the use of bacteriophages is being implemented to detect these bacteria and their subsequent elimination.

In 2020, Duc et al. discovered the first phage able to reduce the population of three different bacteria: E. coli O157:H7, S. enterica serovar Enteritidis, and serovar Typhimurium. This phage decreased the population in chicken food by more than $1.3 \log \mathrm{CFU} / \mathrm{mL}$ after a $2 \mathrm{~h}$ treatment at $4{ }^{\circ} \mathrm{C}$ and $24{ }^{\circ} \mathrm{C}$ [33]. Zampara et al. fused T5 endolysin and RBP Pb5 (which binds to the bacterial outer membrane ferrichrome transporter FhuA) in different configurations and showed that one of these innolysins named Ec21 was able to reduce E. coli by $2.2 \log$ CFU per unit. Interestingly, innolysin Ec21 also displayed bactericidal activity against E. coli resistant to third-generation cephalosporins, reaching a $3.31 \log$ reduction in cell counts [34].

\subsection{Bacteriophages to Control Campylobacter sp.}

C. jejuni and C. coli are frequent causes of human enteritis around the world. People can get infected with these bacteria by eating contaminated seafood, meat and undercooked poultry products.

Zampara et al. identified phages able to reduce C. jejuni at chilled temperature on contaminated poultry meat. These phages were dependent on capsular polysaccharides (CPSs) for infection, but they reduced bacterial population by at least $0.55 \log$ CFU. The capacity of the two most bactericidal phages was better when combined in a cocktail, obtaining a reduction of $0.73 \log$ CFU [35]. Recently, bacteriophage CJ01 has been tested as a biocontrol agent against C. jejuni in mutton and chicken meat. A reduction of $1.70 \log$ $\mathrm{CFU} / \mathrm{g}$ and $1.68 \log \mathrm{CFU} / \mathrm{g}$ was obtained in treated mutton and chicken meat, respectively, at $4{ }^{\circ} \mathrm{C}$ [36].

\subsection{Bacteriophages to Control Vibrio sp.}

Vibrio sp. is found in tissues and/or organs of various marine algae and animals, like abalones, bivalves, corals, fish, shrimp, sponges, squid, and zooplankton. The CDC estimates that Vibrio causes approximately 52,000 foodborne illnesses and 100 deaths in the US every year [37].

A recent study reported that the VVP001 phage specifically infected $V$. vulnificus in a broad range of temperatures ranging from $-20^{\circ} \mathrm{C}$ to $65^{\circ} \mathrm{C}$, showing a reduction of $3.87 \log$ CFU of bacteria on seafood [38]. Zang et al. showed that the OMN phage inactivated $90 \%$ and $99 \%$ of $V$. parahaemolyticus on oyster meat surface after 48 and $72 \mathrm{~h}$, respectively, when it was applied directly on meat [39]. Jun et al. isolated and tested the pVp-1 phage against the pandemic multidrug resistant $V$. parahaemolyticus strain named CRS 09-17. Oysters were treated with a $72 \mathrm{~h}$ immersion with the phage and the bacterial reduction was of $4 \log$ compared to the control group, while the direct treatment on the oyster surfaces reduced the CFU of bacteria by $6 \log [40]$. 


\section{Phage Therapy for Animals}

Phage administration is an interesting alternative to antibiotics in animals. Many in vitro experiments against pathogenic bacteria infecting animals have been reported. Here we focus on recent in vivo studies to show the state of the art in this field (Table 2).

In farms, phage therapy has been studied to treat and prevent infections caused by Salmonella enterica serovar Kentucky and Escherichia coli in chickens. Two S. enterica serovar Kentucky and three E. coli $\mathrm{O} 119$ phages were able to reduce mortality from $30 \%$ in positive control groups up to $0 \%$ in treated chickens. Notably, the higher reduction of bacteria counts in cecum, heart and liver was obtained at day 23 [41].

Recently, a bacteriophage cocktail was used against Pseudomonas aeruginosa that produces rhinosinusitis in sheep. A mix of four phages was able to reduce biofilm biomass on frontal sinus mucosa at concentrations of $10^{8}-10^{10} \mathrm{PFU} / \mathrm{mL}$ with no safety concerns [42].

Several murine mastitis models have showed that phage therapy could be also used against Staphylococcus aureus in bovine mastitis caused by microbial infection [43-45]. A previous study published in 2006 by Gill et al. analyzed the efficacy of a 5-day treatment consisting of phage $\mathrm{K}$ administered intramammary in lactating Holstein cows with subclinical mastitis caused by S. aureus. Three out of 18 animals were cured $(16.7 \%)$ compared to none out of 20 cows of the negative control group (0\%) [46]. Despite some success, the low efficacy could be explained by the data of Gill et al. showing that incubation of S. aureus with whey and bovine serum resulted in inhibition of phage $\mathrm{K}$ lysis. Accordingly, they concluded that proteins could block sterically the phage K attachment to the bacteria, suggesting that $S$. aureus could be more resistant to phages in vivo in mastitis infections than in vitro experiments [47].

Infections caused by E. coli O157:H7 and treatment with phage therapy in ruminants have been already reviewed [48], revealing that further understanding of phage administration, effective multiplicity of infection (MOI) and correct analysis of results are necessary in cattle phage therapy [49-51]. In sheep, no significant reductions of E. coli O157:H7 were found compared to controls when a single phage was administered after oral E. coli inoculation [52,53]. However, a mix of two phages reduced more than $99 \%$ the presence of E. coli in the lower intestinal tracts of treated animals [54]. In addition, a cocktail of eight phages reduced significantly fecal E. coli O157:H7, although not in the rumen, after $24 \mathrm{~h}$ post phage administration [55].

In piglet studies, phages were able to kill methicillin-resistant S. aureus (MRSA) in vitro but no reduction was observed in the nasal mucosa in vivo or ex vivo [56]. This fact emphasizes the importance of considering other factors that may counteract phage efficacy in vivo, such as reduced adherence or increased clearance by the animal fluids. However, experiments conducted in growing pigs showed that dietary supplementation with a commercial cocktail of phages against Salmonella enterica, S. aureus, E. coli and Clostridium prefringens was more efficient than probiotics as growth promoters [57], improving food digestibility, daily weight gain and gain per feed, among other parameters.

The presence of wounds is relatively common in swine. An hydrogel containing phages against Acinetobacter baumanii was used to reduce wound infections in an ex vivo model of pig skin, and achieved a $90 \%$ reduction in bacterial counts after only $4 \mathrm{~h}$ of treatment [58].

Another study showed that seven phages isolated from pig farms in the United Kingdom were able to lyse all 68 Salmonella strains tested, including MDR ones, offering a valuable alternative to antimicrobials to reduce infections and food poisoning [59].

Another recent review [60] summarized the known phages infecting Paenibacillus larvae. This spore-forming bacterium attacks honeybee larvae causing the American foulbrood, which is the most widespread and destructive of the honeybee brood diseases, being able to destroy an entire colony in just three weeks. Importantly, all known bacteriophages against $P$. larvae to date are lysogenic. Despite that, studies of phage therapy in vitro and in hives have shown higher survival rates of treated groups including prophylactic benefits. 
Lack of success in some cases was attributed to the lysogenic nature of the phages or their inability to access the gut.

In aquaculture, the common carp has been used as a model to demonstrate the effectiveness of phage therapy against Citrobacter freundii, using a single phage, IME-JL8. This bacterium belongs to the normal flora of fishes; however, it has been associated to systemic infection in common carp and other diseases in diverse fishes. Administration of phages into the carp decreased pro-inflammatory cytokines and protected the fish from infection when phages were administered one hour after bacteria inoculation, but not after $24 \mathrm{~h}$, indicating that timing is relevant in phage therapy [61]. Similarly, no adverse inflammatory response was induced by the ETP-1 phage in zebrafish (Danio rerio), and twelve days of exposition to ETP-1 was able to increase survival from $18 \%$ in the control group up to $68 \%$ after infection with Edwardsiella tarda bacteria [62]. Another example can be found in the North African catfish (Clarias gariepinus). Ulcerative lesions caused by P. aeruginosa in North African catfish were reduced seven fold compared with untreated control after 8-10 days of treatment with a single phage [63]. In addition, treatment with two different phages at MOI of 100 reached $100 \%$ of survival in Vietnamese striped catfish (Pangasianodon hypophthalmus) infected with Aeromonas hydrophila, which produces hemorrhagic septicemia, compared to $13 \%$ of survival in the control group [64].

Vibrio sp. produce mortality in bivalve larvae and bacteriophages could be used as biocontrol agents in oyster hatcheries. Two different approaches have been described to solve this problem. The first consists on direct phage treatment comprising two phages, which diminished mortality rates from $77.9 \%$ in the control group to $28.2 \%$ after just $24 \mathrm{~h}$ of incubation [65]. However, the second approach focuses on decontaminating microalgae as vectors for Vibrio sp. infection of larval cultures. Phage administration in microalgae resulted in significant reduction of Vibrio sp. within $2 \mathrm{~h}$, suggesting that feeding larvae with decontaminated microalgae could be a promising preventive method to avoid infection of bivalve larvae [66]. Curiously, in 2019, a study using a heterologous expression vector was performed against Vibrio parahaemolyticus. The yeast Pichia pastoris X-33 expressed the phage endolysin Vplys60 from bacteriophage qdv001 and the enzyme was shown to inhibit biofilm formation and to reduce mortality rates for the crustacean Artemia franciscana [67]. In other studies, a phage treatment with two phages against Vibrio anguillarum infection was effective at $72 \mathrm{~h}$ in zebrafish larvae [68], and a cocktail of three phages isolated from sewage showed host specificity against eight Vibrio coralliilyticus strains and a Vibrio tubiashii strain, obtaining a decrease of over $90 \%$ in V. coralliilyticus compared to the untreated control [69].

Table 2. Summary of reviewed studies using phage therapy in animals.

\begin{tabular}{|c|c|c|c|c|c|}
\hline Animal & Infection/Colonization & Bacteria & Phage Therapy & Outcome & References \\
\hline Chicken & $\begin{array}{l}\text { Salmonellosis and } \\
\text { colibacillosis }\end{array}$ & $\begin{array}{l}\text { S. enterica serovar } \\
\text { Kentucky and } \\
\text { Escherichia coli O119 }\end{array}$ & $\begin{array}{c}\text { Siphoviridae }\left(10^{7} \mathrm{PFU}\right) \text { against } \\
\text { serovar } \\
\text { Kentucky and Podoviridae (10 } \\
\text { PFU) against Escherichia coli } \\
\text { orally }\end{array}$ & $\begin{array}{l}\text { Reduction of mortality from } \\
30 \% \text { to } 0 \% \text { in treated group }\end{array}$ & {$[41]$} \\
\hline Sheep & Rhinosinusitis & Pseudomonas aeruginosa & $\begin{array}{c}\text { Cocktail of } 4 \text { phages }(\mathrm{Pa} 193, \\
\mathrm{Pa} 204, \mathrm{~Pa} 222, \text { and } \mathrm{Pa} 223) \text { at } \\
10^{8}-10^{10} \mathrm{PFU} / \mathrm{mL}\end{array}$ & $\begin{array}{l}\text { Reduction of biofilm biomass } \\
\text { on sinus mucosa }\end{array}$ & [42] \\
\hline Cow & Subclinical mastitis & Staphylococcus aureus & $\begin{array}{c}\text { Phage K }\left(10^{11} \mathrm{PFU}\right) \\
\text { intramammary infusions for } 5 \\
\text { days }\end{array}$ & $\begin{array}{l}\text { 3/18 cows were cured } \\
\text { compared to } 0 / 20 \text { of control } \\
\text { group }\end{array}$ & [46] \\
\hline Sheep & Gut & Escherichia coli O157:H7 & $\begin{array}{c}\text { Oral phage KH1 }\left(10^{11} \mathrm{PFU}\right) \text { or } \\
\text { DC22 }\left(10^{13} \mathrm{PFU}\right)\end{array}$ & No reduction of strain O157:H7 & {$[52,53]$} \\
\hline Sheep & Gut & Escherichia coli O157:H7 & $\begin{array}{l}\text { Cocktail of CEV1 (T4-like) and } \\
\text { CEV2 (T5-like) orally }\end{array}$ & $\begin{array}{l}\text { Reduction }>99 \% \text { of Escherichia } \\
\text { coli in the lower intestinal tract }\end{array}$ & [54] \\
\hline Sheep & Gut & Escherichia coli O157:H7 & Cocktail of 8 phages orally & $\begin{array}{l}\text { Reduction of fecal Escherichia } \\
\text { coli O157:H7, but not in the } \\
\text { rumen, } 24 \mathrm{~h} \text { after phage } \\
\text { administration }\end{array}$ & [55] \\
\hline Pig & Nasal colonization & $\begin{array}{l}\text { MRSA V0608892/1 } \\
\text { strain }\end{array}$ & $\begin{array}{c}\text { P68 (Podovirus) and } \mathrm{K}^{*} 710 \\
\text { (Myovirus) in gel }\end{array}$ & $\begin{array}{c}\text { No reduction observed in the } \\
\text { nasal mucosa }\end{array}$ & [56] \\
\hline
\end{tabular}


Table 2. Cont.

\begin{tabular}{|c|c|c|c|c|c|}
\hline Animal & Infection/Colonization & Bacteria & Phage Therapy & Outcome & References \\
\hline Pig & Prevention & $\begin{array}{l}\text { Salmonella enterica, } \\
\text { Staphylococcus aureus, } \\
\text { Escherichia coli and } \\
\text { Clostridium prefringens }\end{array}$ & Cocktail of phages orally & $\begin{array}{l}\text { Compared to probiotics, } \\
\text { phages had better results as } \\
\text { growth promoters, improving } \\
\text { digestibility, daily weight gain } \\
\text { and gain per feed }\end{array}$ & [57] \\
\hline Pig & Ex vivo skin infection & Acinetobacter baumannii & IME-AB2 (Myoviridae) via gel & $\begin{array}{l}\text { Reduction of } 90 \% \text { of bacterial } \\
\text { counts } 4 \text { h post-treatment }\end{array}$ & [58] \\
\hline Honeybee larvae & American foulbrood & Paenibacillus larvae & Cocktail of phages 1,5 and 9 & $\begin{array}{l}\text { Higher survival rates in hives } \\
\text { of treated groups including } \\
\text { prophylactic benefits }\end{array}$ & {$[60,70]$} \\
\hline Common carp & Sepsis & Citrobacter freundii & IME-JL8 (Siphoviridae) & $\begin{array}{l}\text { Decreased pro-inflammatory } \\
\text { cytokines and protection of fish } \\
\text { from infection when phages } \\
\text { were administered } 1 \mathrm{~h} \text { after } \\
\text { bacteria, but not after } 24 \mathrm{~h}\end{array}$ & {$[61]$} \\
\hline Zebrafish & Sepsis & Edwardsiella tarda & ETP-1 for $12 \mathrm{~d}$ & $\begin{array}{l}\text { Increment of survival from } 18 \% \\
\text { to } 68 \%\end{array}$ & {$[62]$} \\
\hline $\begin{array}{l}\text { North African } \\
\text { catfish }\end{array}$ & Ulcerative lesions & Pseudomonas aeruginosa & Single phage for $8-10 \mathrm{~d}$ & $\begin{array}{l}\text { 7-fold reduction of ulcerative } \\
\text { lesions }\end{array}$ & [63] \\
\hline $\begin{array}{l}\text { Vietnamese striped } \\
\text { catfish }\end{array}$ & $\begin{array}{l}\text { Hemorrhagic } \\
\text { septicemia }\end{array}$ & Aeromonas hydrophila & $\Phi 2$ and $\Phi 5$ & $\begin{array}{l}\text { Increment of survival from } 13 \% \\
\text { to } 100 \%\end{array}$ & [64] \\
\hline Bivalve larvae & Infection & Vibrio sp. & Cocktail of $\Phi 5, \Phi 6$ and $\Phi 7$ & $\begin{array}{l}\text { Reduction of mortality from } \\
77.9 \% \text { to } 28.2 \%\end{array}$ & [65] \\
\hline $\begin{array}{l}\text { Microalgae food of } \\
\text { bivalve larvae }\end{array}$ & Infection & Vibrio harveyi & Cocktail of $\Phi 1, \Phi 2, \Phi 3$ and $\Phi 4$ & $\begin{array}{l}10 \text { times reduction of bacteria } \\
\text { after } 2 \mathrm{~h}\end{array}$ & {$[66]$} \\
\hline Zebrafish larvae & Infection & Vibrio anguillarum & VA-1 phage & $\begin{array}{c}\text { Mortality rate after } 72 \\
\text { post-infection was reduced } \\
\text { from } 17 € \text { to } 3 \% .\end{array}$ & [68] \\
\hline $\begin{array}{l}\text { Larval Pacific } \\
\text { oysters }\end{array}$ & Infection & Vibrio coralliilyticus & $\begin{array}{c}\text { Cocktail of vB_VcorM-GR7B, } \\
\text { vB_VcorM-GR11A, and } \\
\text { vB_VcorM-GR28A }\end{array}$ & $\begin{array}{l}\text { Mortality reduction of }>90 \% \\
\text { respect to the control group }\end{array}$ & [69] \\
\hline
\end{tabular}

Abbreviations: PFU, plaque-forming units; MRSA, methicillin-resistant Staphylococcus aureus.

These studies reveal that current results are more promising in aquaculture than in farms. More studies are needed to clarify the real sanitary and economic potential of phagebased therapies in the food industry. It is possible that, as it happens in humans, better results could be obtained by mixing phages and antibiotics due to the synergistic effect.

\section{Phage Therapy for Plants}

Different pathogenic bacteria produce significant economic losses in plant production worldwide. This section focuses on recent advances in phage use against pathogens infecting economically relevant plants such as potatoes, tomatoes, cherries, onions, kohlrabies and melons.

Potatoes: Pectobacterium atrosepticum is a pathogenic bacterium causing soft rot disease and blackleg disease. A cocktail of six phages infected $93 \%$ of tested strains and succeeded for biocontrol by decreasing disease incidence (61\%) and severity (64\%) [71]. Another study treated a mixed infection caused by two different $P$. atrosepticum strains with a cocktail of three bacteriophages and the results showed that the average weight of rotten tissue decreased significantly from $5.39 \mathrm{~g}$ in infected plants to $0.31 \mathrm{~g}$ in treated tubers [72]. Semiin planta potato bioassays showed that a cocktail of six phages were able to suppress the growth of a mix of $P$. atrosepticum and P. carotovorum subsp. carotovorum against soft rot development [73]. Curiously, another study described that phage Pc1 infects P. carotovorum subsp. carotovorum more efficiently when zinc is not present in the medium, suggesting that inorganic composition of soil is relevant when phage therapy is considered for biocontrol [74]. On the contrary, a Tasmanian potato farm study showed the protective effect of beneficial streptomycetes in soil and pointed that in case of treating the pathogenic strains of Streptomyces with phage therapy, a preliminary host range analysis should be performed since a deleterious effect against beneficial streptomycetes might produce opportunistic fungal infections [75]. In a different studio, a cocktail of six phages was used 
to combat the potato pathogen Dickeya solani in soft rots. The cocktail was able to reduce the disease incidence in infected tubers from $93.3 \%$ to $48.9 \%$ and decrease the diseased tissue by $75.3 \%$ [76]. Similar results were found previously with T4-related phages. The treatment of rotting of potato tubers with one phage decreased weight of rot from $4 \mathrm{~g}$ to $0.5 \mathrm{~g}$ at MOI of 100 [77]. Interestingly, the injection of six phages prior infection protected $80 \%$ of potato plants from the Ralstonia solanacearum wilt. Phage treatment of contaminated soil also reduced more than 5-fold the presence of this pathogenic bacteria compared to the control soil one week after phage spraying. Efficiency was shown to depend on timing of phage administration, suggesting that phage administration should be performed just after the first sign of bacterial wilt [78].

Tomatoes: Several studios with tomato plants are available in the literature. The application of phage PE204 to the root system of tomato plants completely inhibited bacterial wilt caused by R. solanacearum [79]. Phages isolated from river water also reduced significantly bacterial wilt and cocktails were the most effective candidates [80]. A greenhouse experiment with combinations of phages against $R$. solanacearum suggested that cocktails of phages select slow-growing resistant bacteria which reduces the severity of the disease [81]. Importantly, a seedling-based method has been recently developed by mixing phages and tomato seedlings in sterile conical tubes before applying Pseudomonas syringae to screen phage effectiveness. The authors propose this method before choosing phage candidates in phage biocontrol [82].

Cherries: A treatment with thirteen individual phages or two cocktails produced a reduction in the disease progression and a decrease of $15-40 \%$ of $P$. syringae in cherry leaves [83].

Onions: Recently, a phage-biocontrol study was performed against soft rot caused by Pectobacterium sp. in onions using field trials. The results showed significant higher number of plants in the treatments compared to the positive controls, with concomitant increased bulb and foliage mass and also reduced soft rot disease symptoms [84].

Kohlrabies: The administration of a single phage at a MOI of 10 was able to reduce black rot disease symptoms due to Xanthomonas campestris pv. campestris up to 45\% [85].

Melons: Acidovorax citrulli causing fruit blotch was treated with a single phage and $27 \%$ of disease severity was shown compared with $80 \%$ of disease of the control group, moreover, phage was detected by PCR in foliar tissues $8 \mathrm{~h}$ after phage addition to the soil [86].

Summarizing, the use of phage-biocontrol shows a certain effect in vegetables, mainly when cocktails are administered in a short period time after infection. If this strategy results beneficial, it could be administered in the irrigation water to help decrease losses caused by pathogenic bacteria in cultures of economic relevance.

\section{Phages on Surfaces}

Bacteria are able to attach different surfaces as glass, metals, polymers, foods, as well as to other organisms [87]. The greatest risk of food contamination resides on food-contact surfaces. For this reason, biofilms are a big deal in food industry, since they can spoil the equipment and contaminate food, increasing production costs [88]. The interactions between bacteria and food-processing surfaces begins with a non-specific adhesion and ends with specific adhesions and the biofilm formation [89].

Salmonella fimbriae facilitate attachment and the presence of cellulose enhances biofilm formation on certain abiotic surfaces [90]. In 2019, Islam et al. isolated three broadranged lytic phages, LPSTLL, LPST94 and LPST153, from environmental water samples. The cocktail reduced Salmonella biofilms by $44-63 \%$ on $96-$ well microplates. On foodprocessing surfaces such as stainless steel the cocktail was able to reduce biofilms cells up to $6.42 \log$ CFU [91]. Remarkably, Sadekuzzaman et al. showed that bacteriophages reduced Salmonella in biofilms after only two hours of treatment by 3 and $2 \log \mathrm{CFU} / \mathrm{cm}^{2}$ on stainless steel and rubber, respectively, while adhered viable cells on lettuce were reduced around $1 \log$ CFU per unit [92]. Gong et al. exhibited that a cocktail of six phages was able 
to diminish by $84.2 \%$ the Salmonella population on the boots of workers (which is relevant to prevent re-contamination of rendered meals) in a rendering-processing environment. This reduction increased in combination with sodium hypochlorite $(92.9 \%)$ and scrubbing $(93.2 \%)$ after a treatment three times for one week [93]. Interestingly, it has been shown a synergistic effect in the combination of bacteriophages and chlorine with a reduction of biofilm growth by $94 \%$ and the ability to remove pre-existing biofilms by $88 \%$, whereas chlorine alone could not eliminate them [94].

Pseudomonas is the most frequently reported genus of the bacteria found after sanitation on food processing surfaces. This genus is able to resist in niches with nutrients, surface materials, temperatures and stress factors that are problematic for other bacteria, such as machines, floors, drains or stainless steel [95]. Magin et al. tested 14.1 and LUZ7 phages isolated from drinking and thermal water against $24 \mathrm{~h}$ old biofilms produced by P. aeruginosa $\mathrm{PAO} 1$ and D1 strains. Results showed that phage treatment produced a reduction of $1.7 \log \mathrm{CFU} / \mathrm{cm}^{2}$ of bacteria in biofilms formed on stainless-steel surface compared with untreated biofilms [96].

On the other hand, E. coli can attach to a variety of surfaces including stainless steel, teflon, glass, polystyrene, polypropylene, PVC and biotic surfaces, which are commonly employed in food industry. Wang et al. tested the AZO145A phage against the Shiga toxigenic E. coli O145:H25 strain, known to be a strong biofilm former, on stainless steel coupons. Bacteriophage addition on biofilms grown during 24,48 and $72 \mathrm{~h}$ was able to reduce cells 2.9, 1.9 and $1.9 \log \mathrm{CFU} /$ coupon, respectively, compared to the control [97].

Overall, bacteriophages show great promise in decreasing the formation of new biofilms, but most importantly, in removing pre-existing ones in combination with other agents such as bleach.

\section{Bacteriophages in Bioremediation}

Most of the hydrocarbons contaminating water can be used as a source of carbon by a large number of bacteria such as $P$. aeruginosa, which is capable of degrading monoaromatic hydrocarbons [98] or with species of Rhodococcus genus, capable of degrading cyclohexane [99]. Recent studies have identified bacteria from more than 79 genera capable of degrading petroleum hydrocarbons [100]. The employment of microorganisms in bioremediation is based on the microbial loop. The main role of the microbial loop is the fast $\mathrm{CO}_{2}$ production and the recycle of nitrogen and phosphorus in the environment [101]. Rosenberg et al. tested the efficiency of two bioreactors with bacteria/phage combinations at different concentrations for the treatment of drainage water from an Israeli oil terminal. Their study showed a total organic carbon reduction of $85 \%$ in the bioreactor with less bacteriophages and $90 \%$ of reduction with a higher phage concentration compared to the control, which supports the concept of a phage-driven microbial loop [102]. Phages can immobilize some nitrogen or phosphorus, but the main impact is caused by the bacterial lysis and the release of constituents into the water as dissolved organic Carbon, thereby increasing the bacterial growth $[102,103]$.

On the other hand, phages have been also tested to help in the treatment of activated sludge bulking and foaming. Khainar et al. isolated specific bacteriophages against nocardioforms on active sludge process. The activity of three phages applied in a cocktail at the lab scale reactor reduced foam formation [104]. Choi et al. isolated a bacteriophage from sewage infecting Sphaerotilus natans, known to cause filamentous bulking in wastewater treatment systems, and their results showed that phage application diminished the sludge volume index and turbidity of the supernatant, indicating that phages can be used in this concern too [105].

\section{Discussion}

Phages are promising candidates in the fight against MDR bacteria. Recent studies report that phage treatment is able to reduce bacterial load and biofilm formation in biotic and abiotic media, indicating that this approach can be useful in biotechnology. However, 
one of the main concerns when considering this alternative is the narrow host range of most of the phages. This can be reverted almost completely with the use of phage cocktails. Moreover, cocktail use decreases the appearance of phage-resistant strains. High MOI and a rapid administration have been shown to increase successful rates of phage therapy in controlled experiments, however, in the real practice these two parameters cannot be determined.

Two different approaches of phage therapy have been proposed depending on the goal, humans and non-humans. In the first case, phage therapy is administered usually in combination with antibiotics due to their synergistic effect, while in the second case studies are performed typically only with phages to avoid antibiotics. Lessons learnt for human use could be helpful to succeed in non-human practice. Successful case reports in humans usually have administered cocktails of phages combined with antibiotics in multiple doses. Therefore, the combination of cocktails and low levels of antibiotics could improve the results of ineffective phage therapy in non-human use. On the other hand, there are cases in which neither antimicrobials nor phages can solve the injury, such as the case of toxigenic strains in which the harmful effect is due to the toxin. A less explored alternative is the induction of prophages that are latent in the bacterial genomes [106] with compounds like EDTA, sodium citrate [107], glycolic acid, N-acetyl cysteine, vinegar or plant extracts like stevia [108], which would solve issues such as the host range restriction or bacterial resistance, and would improve the reaching to intracellular bacteria [106].

In conclusion, further research is necessary to elaborate standard protocols in each specific field, including farms, aquaculture, surfaces or bioremediation in terms of timing, administration or cocktail composition, although the current phage products available in the market show that this alternative is already a real choice in biocontrol.

Funding: Project PI20/00261, funded by Instituto de Salud Carlos III and co-funded by European Union (ESF, "Investing in your future"). MG-Q is supported by the Subprograma Miguel Servet from the Ministerio de Ciencia e Innovación of Spain (CP19/00104), Instituto de Salud Carlos III (Plan Estatal de I+D+i 2017-2020), and co-funded by the European Social Fund "Investing in your future".

Conflicts of Interest: The authors declare no conflict of interest.

\section{References}

1. Kulinkina, A.; Shinee, E.; Herrador, B.R.G.; Nygard, K.; Schmoll, O. The Situation of Water-Related Infectious Diseases in the Pan-European Region. World Health Organization. Regional Office for Europe. 2016. Available online: https://apps.who.int/ iris/handle/10665/329534 (accessed on 11 June 2021).

2. Van Boeckel, T.P.; Brower, C.; Gilbert, M.; Grenfell, B.T.; Levin, S.A.; Robinson, T.P.; Teillant, A.; Laxminarayan, R. Global Trends in Antimicrobial Use in Food Animals. Proc. Natl. Acad. Sci. USA 2015, 112, 5649-5654. [CrossRef]

3. Ma, F.; Xu, S.; Tang, Z.; Li, Z.; Zhang, L. Use of Antimicrobials in Food Animals and Impact of Transmission of Antimicrobial Resistance on Humans. Biosaf. Health 2021, 3, 32-38. [CrossRef]

4. Broncano-Lavado, A.; Santamaría-Corral, G.; Esteban, J.; García-Quintanilla, M. Advances in Bacteriophage Therapy against Relevant Multidrug-Resistant Pathogens. Antibiotics 2021, 10, 672. [CrossRef]

5. Kasman, L.M.; Porter, L.D. Bacteriophages. In StatPearls; StatPearls Publishing: Treasure Island, FL, USA, 2021.

6. Ghose, C.; Euler, C.W. Gram-Negative Bacterial Lysins. Antibiotics 2020, 9, 74. [CrossRef] [PubMed]

7. Labrie, S.J.; Samson, J.E.; Moineau, S. Bacteriophage Resistance Mechanisms. Nat. Rev. Microbiol. 2010, 8, 317-327. [CrossRef]

8. Harada, L.K.; Silva, E.C.; Campos, W.F.; Del Fiol, F.S.; Vila, M.; Dąbrowska, K.; Krylov, V.N.; Balcão, V.M. Biotechnological Applications of Bacteriophages: State of the Art. Microbiol. Res. 2018, 212-213, 38-58. [CrossRef] [PubMed]

9. CDC. Centers for Disease Control and Prevention. Available online: Https://Www.Cdc.Gov/Foodsafety/Foods-Linked-Illness. Html (accessed on 11 June 2021).

10. EFSA. Salmonella the Most Common Cause of Foodborne Outbreaks in the European Union; European Food Safety Authority: Parma, Italy, 2019.

11. Thung, T.Y.; Krishanthi Jayarukshi Kumari Premarathne, J.M.; San Chang, W.; Loo, Y.Y.; Chin, Y.Z.; Kuan, C.H.; Tan, C.W.; Basri, D.F.; Jasimah Wan Mohamed Radzi, C.W.; Radu, S. Use of a Lytic Bacteriophage to Control Salmonella Enteritidis in Retail Food. LWT 2017, 78, 222-225. [CrossRef]

12. Phongtang, W.; Choi, G.-P.; Chukeatirote, E.; Ahn, J. Bacteriophage Control of Salmonella Typhimurium in Milk. Food Sci. Biotechnol. 2019, 28, 297-301. [CrossRef] 
13. Bao, H.; Zhang, P.; Zhang, H.; Zhou, Y.; Zhang, L.; Wang, R. Bio-Control of Salmonella Enteritidis in Foods Using Bacteriophages. Viruses 2015, 7, 4836-4853. [CrossRef] [PubMed]

14. PhageGuard. Available online: Https:/ / Phageguard.Com/Salmonella-Solution/ (accessed on 11 June 2021).

15. Yeh, Y.; Purushothaman, P.; Gupta, N.; Ragnone, M.; Verma, S.C.; de Mello, A.S. Bacteriophage Application on Red Meats and Poultry: Effects on Salmonella Population in Final Ground Products. Meat Sci. 2017, 127, 30-34. [CrossRef] [PubMed]

16. Silk, B.J.; Date, K.A.; Jackson, K.A.; Pouillot, R.; Holt, K.G.; Graves, L.M.; Ong, K.L.; Hurd, S.; Meyer, R.; Marcus, R.; et al. Invasive Listeriosis in the Foodborne Diseases Active Surveillance Network (FoodNet), 2004-2009: Further Targeted Prevention Needed for Higher-Risk Groups. Clin. Infect. Dis. Off. Publ. Infect. Dis. Soc. Am. 2012, 54 (Suppl. 5), S396-S404. [CrossRef]

17. Slany, M.; Oppelt, J.; Cincarova, L. Formation of Staphylococcus Aureus Biofilm in the Presence of Sublethal Concentrations of Disinfectants Studied via a Transcriptomic Analysis Using Transcriptome Sequencing (RNA-Seq). Appl. Environ. Microbiol. 2017, 83, e01643-17. [CrossRef] [PubMed]

18. Kawacka, I.; Olejnik-Schmidt, A.; Schmidt, M.; Sip, A. Effectiveness of Phage-Based Inhibition of Listeria Monocytogenes in Food Products and Food Processing Environments. Microorganisms 2020, 8, 1764. [CrossRef] [PubMed]

19. Żbikowska, K.; Michalczuk, M.; Dolka, B. The Use of Bacteriophages in the Poultry Industry. Animals 2020, 10, 872. [CrossRef]

20. Loessner, M.J.; Wendlinger, G.; Scherer, S. Heterogeneous Endolysins in Listeria Monocytogenes Bacteriophages: A New Class of Enzymes and Evidence for Conserved Holin Genes within the Siphoviral Lysis Cassettes. Mol. Microbiol. 1995, 16, 1231-1241. [CrossRef]

21. Gutiérrez, D.; Rodríguez-Rubio, L.; Fernández, L.; Martínez, B.; Rodríguez, A.; García, P. Applicability of Commercial PhageBased Products against Listeria Monocytogenes for Improvement of Food Safety in Spanish Dry-Cured Ham and Food Contact Surfaces. Food Control 2017, 73, 1474-1482. [CrossRef]

22. Yang, S.; Sadekuzzaman, M.; Ha, S. Reduction of Listeria Monocytoogenes on Chicken Breasts by Combined Treatment with UV-C Light and Bacteriophage ListShield. LWT 2017, 86, 193-200. [CrossRef]

23. Carlton, R.M.; Noordman, W.H.; Biswas, B.; de Meester, E.D.; Loessner, M.J. Bacteriophage P100 for Control of Listeria Monocytogenes in Foods: Genome Sequence, Bioinformatic Analyses, Oral Toxicity Study, and Application. Regul. Toxicol. Pharmacol. 2005, 43, 301-312. [CrossRef] [PubMed]

24. Soni, K.A.; Nannapaneni, R.; Hagens, S. Reduction of Listeria Monocytogenes on the Surface of Fresh Channel Catfish Fillets by Bacteriophage Listex P100. Foodborne Pathog. Dis. 2010, 7, 427-434. [CrossRef]

25. Soni, K.A.; Nannapaneni, R. Bacteriophage Significantly Reduces Listeria Monocytogenes on Raw Salmon Fillet Tissue. J. Food Prot. 2010, 73, 32-38. [CrossRef]

26. Soni, K.A.; Desai, M.; Oladunjoye, A.; Skrobot, F.; Nannapaneni, R. Reduction of Listeria Monocytogenes in Queso Fresco Cheese by a Combination of Listericidal and Listeriostatic GRAS Antimicrobials. Int. J. Food Microbiol. 2012, 155, 82-88. [CrossRef] [PubMed]

27. Soni, K.A.; Nannapaneni, R. Removal of Listeria Monocytogenes Biofilms with Bacteriophage P100. J. Food Prot. 2010, 73, 1519-1524 [CrossRef] [PubMed]

28. Miguéis, S.; Saraiva, C.; Esteves, A. Efficacy of LISTEX P100 at Different Concentrations for Reduction of Listeria Monocytogenes Inoculated in Sashimi. J. Food Prot. 2017, 80, 2094-2098. [CrossRef] [PubMed]

29. Silva, E.N.G.; Figueiredo, A.C.L.; Miranda, F.A.; Almeida, R.C.d.C. Control of Listeria Monocytogenes Growth in Soft Cheeses by Bacteriophage P100. Braz. J. Microbiol. 2014, 45, 11-16. [CrossRef]

30. Komora, N.; Maciel, C.; Pinto, C.A.; Ferreira, V.; Brandão, T.R.S.; Saraiva, J.M.A.; Castro, S.M.; Teixeira, P. Non-Thermal Approach to Listeria Monocytogenes Inactivation in Milk: The Combined Effect of High Pressure, Pediocin PA-1 and Bacteriophage P100. Food Microbiol. 2020, 86, 103315. [CrossRef]

31. ECDC. European Centre for Disease Prevention and Control. Available online: Https://Www.Ecdc.Europa.Eu/En/EscherichiaColi-Ecoli/Facts (accessed on 11 June 2021).

32. CDC. Centers for Disease Control and Prevention. Available online: Https:/ /Www.Cdc.Gov/Ecoli / (accessed on 11 June 2021).

33. Duc, H.M.; Son, H.M.; Yi, H.P.S.; Sato, J.; Ngan, P.H.; Masuda, Y.; Honjoh, K.; Miyamoto, T. Isolation, Characterization and Application of a Polyvalent Phage Capable of Controlling Salmonella and Escherichia Coli O157:H7 in Different Food Matrices. Food Res. Int. 2020, 131, 108977. [CrossRef]

34. Zampara, A.; Sørensen, M.C.H.; Grimon, D.; Antenucci, F.; Vitt, A.R.; Bortolaia, V.; Briers, Y.; Brøndsted, L. Exploiting Phage Receptor Binding Proteins to Enable Endolysins to Kill Gram-Negative Bacteria. Sci. Rep. 2020, 10, 12087. [CrossRef]

35. Zampara, A.; Sørensen, M.C.H.; Elsser-Gravesen, A.; Brøndsted, L. Significance of Phage-Host Interactions for Biocontrol of Campylobacter Jejuni in Food. Food Control 2017, 73, 1169-1175. [CrossRef]

36. Thung, T.Y.; Lee, E.; Mahyudin, N.A.; Wan Mohamed Radzi, C.W.J.; Mazlan, N.; Tan, C.W.; Radu, S. Partial Characterization and in Vitro Evaluation of a Lytic Bacteriophage for Biocontrol of Campylobacter Jejuni in Mutton and Chicken Meat. J. Food Saf. 2020, 40. [CrossRef]

37. CDC. Centers for Disease Control and Prevention. Available online: Https://Www.Cdc.Gov/Vibrio/Faq.Html (accessed on 11 June 2021).

38. Kim, H.-J.; Kim, Y.-T.; Kim, H.B.; Choi, S.H.; Lee, J.-H. Characterization of Bacteriophage VVP001 and Its Application for the Inhibition of Vibrio Vulnificus Causing Seafood-Borne Diseases. Food Microbiol. 2021, 94, 103630. [CrossRef] 
39. Zhang, H.; Yang, Z.; Zhou, Y.; Bao, H.; Wang, R.; Li, T.; Pang, M.; Sun, L.; Zhou, X. Application of a Phage in Decontaminating Vibrio Parahaemolyticus in Oysters. Int. J. Food Microbiol. 2018, 275, 24-31. [CrossRef]

40. Jun, J.W.; Kim, H.J.; Yun, S.K.; Chai, J.Y.; Park, S.C. Eating Oysters without Risk of Vibriosis: Application of a Bacteriophage against Vibrio Parahaemolyticus in Oysters. Int. J. Food Microbiol. 2014, 188, 31-35. [CrossRef] [PubMed]

41. Sorour, H.K.; Gaber, A.F.; Hosny, R.A. Evaluation of the Efficiency of Using Salmonella Kentucky and Escherichia Coli O119 Bacteriophages in the Treatment and Prevention of Salmonellosis and Colibacillosis in Broiler Chickens. Lett. Appl. Microbiol. 2020, 71, 345-350. [CrossRef]

42. Fong, S.A.; Drilling, A.J.; Ooi, M.L.; Paramasivan, S.; Finnie, J.W.; Morales, S.; Psaltis, A.J.; Vreugde, S.; Wormald, P.-J. Safety and Efficacy of a Bacteriophage Cocktail in an in Vivo Model of Pseudomonas Aeruginosa Sinusitis. Transl. Res. 2019, 206, 41-56. [CrossRef]

43. Iwano, H.; Inoue, Y.; Takasago, T.; Kobayashi, H.; Furusawa, T.; Taniguchi, K.; Fujiki, J.; Yokota, H.; Usui, M.; Tanji, Y.; et al. Bacteriophage $\Phi S A 012$ Has a Broad Host Range against Staphylococcus Aureus and Effective Lytic Capacity in a Mouse Mastitis Model. Biology 2018, 7, 8. [CrossRef]

44. Ngassam-Tchamba, C.; Duprez, J.N.; Fergestad, M.; De Visscher, A.; L'Abee-Lund, T.; De Vliegher, S.; Wasteson, Y.; Touzain, F.; Blanchard, Y.; Lavigne, R.; et al. In Vitro and in Vivo Assessment of Phage Therapy against Staphylococcus Aureus Causing Bovine Mastitis. J. Glob. Antimicrob. Resist. 2020, 22, 762-770. [CrossRef]

45. Geng, H.; Zou, W.; Zhang, M.; Xu, L.; Liu, F.; Li, X.; Wang, L.; Xu, Y. Evaluation of Phage Therapy in the Treatment of Staphylococcus Aureus-Induced Mastitis in Mice. Folia Microbiol. 2020, 65, 339-351. [CrossRef] [PubMed]

46. Gill, J.J.; Pacan, J.C.; Carson, M.E.; Leslie, K.E.; Griffiths, M.W.; Sabour, P.M. Efficacy and Pharmacokinetics of Bacteriophage Therapy in Treatment of Subclinical Staphylococcus Aureus Mastitis in Lactating Dairy Cattle. Antimicrob. Agents Chemother. 2006, 50, 2912-2918. [CrossRef] [PubMed]

47. Gill, J.J.; Sabour, P.M.; Leslie, K.E.; Griffiths, M.W. Bovine Whey Proteins Inhibit the Interaction of Staphylococcus Aureus and Bacteriophage K. J. Appl. Microbiol. 2006, 101, 377-386. [CrossRef] [PubMed]

48. Wang, L.; Qu, K.; Li, X.; Cao, Z.; Wang, X.; Li, Z.; Song, Y.; Xu, Y. Use of Bacteriophages to Control Escherichia Coli O157:H7 in Domestic Ruminants, Meat Products, and Fruits and Vegetables. Foodborne Pathog. Dis. 2017, 14, 483-493. [CrossRef]

49. Stanford, K.; McAllister, T.A.; Niu, Y.D.; Stephens, T.P.; Mazzocco, A.; Waddell, T.E.; Johnson, R.P. Oral Delivery Systems for Encapsulated Bacteriophages Targeted at Escherichia Coli O157:H7 in Feedlot Cattle. J. Food Prot. 2010, 73, 1304-1312. [CrossRef] [PubMed]

50. Rozema, E.A.; Stephens, T.P.; Bach, S.J.; Okine, E.K.; Johnson, R.P.; Stanford, K.; McAllister, T.A. Oral and Rectal Administration of Bacteriophages for Control of Escherichia Coli O157:H7 in Feedlot Cattle. J. Food Prot. 2009, 72, 241-250. [CrossRef] [PubMed]

51. Rivas, L.; Coffey, B.; McAuliffe, O.; McDonnell, M.J.; Burgess, C.M.; Coffey, A.; Ross, R.P.; Duffy, G. In Vivo and Ex Vivo Evaluations of Bacteriophages E11/2 and E4/1c for Use in the Control of Escherichia Coli O157:H7. Appl. Environ. Microbiol. 2010, 76, 7210-7216. [CrossRef]

52. Bach, S.J.; McAllister, T.A.; Veira, D.M.; Gannon, V.P.J.; Holley, R.A. Effect of Bacteriophage DC22 on Escherichia Coli O157:H7 in an Artificial Rumen System (Rusitec) and Inoculated Sheep. Anim. Res. 2003, 52, 89-101. [CrossRef]

53. Sheng, H.; Knecht, H.J.; Kudva, I.T.; Hovde, C.J. Application of Bacteriophages to Control Intestinal Escherichia Coli O157:H7 Levels in Ruminants. Appl. Environ. Microbiol. 2006, 72, 5359-5366. [CrossRef] [PubMed]

54. Raya, R.R.; Oot, R.A.; Moore-Maley, B.; Wieland, S.; Callaway, T.R.; Kutter, E.M.; Brabban, A.D. Naturally Resident and Exogenously Applied T4-like and T5-like Bacteriophages Can Reduce Escherichia Coli O157:H7 Levels in Sheep Guts. Bacteriophage 2011, 1, 15-24. [CrossRef]

55. Callaway, T.R.; Edrington, T.S.; Brabban, A.D.; Anderson, R.C.; Rossman, M.L.; Engler, M.J.; Carr, M.A.; Genovese, K.J.; Keen, J.E.; Looper, M.L.; et al. Bacteriophage Isolated from Feedlot Cattle Can Reduce Escherichia Coli O157:H7 Populations in Ruminant Gastrointestinal Tracts. Foodborne Pathog. Dis. 2008, 5, 183-191. [CrossRef]

56. Verstappen, K.M.; Tulinski, P.; Duim, B.; Fluit, A.C.; Carney, J.; van Nes, A.; Wagenaar, J.A. The Effectiveness of Bacteriophages against Methicillin-Resistant Staphylococcus Aureus ST398 Nasal Colonization in Pigs. PLoS ONE 2016, 11, e0160242. [CrossRef]

57. Kim, K.H.; Ingale, S.L.; Kim, J.S.; Lee, S.H.; Lee, J.H.; Kwon, I.K.; Chae, B.J. Bacteriophage and Probiotics Both Enhance the Performance of Growing Pigs but Bacteriophage Are More Effective. Anim. Feed Sci. Technol. 2014, 196, 88-95. [CrossRef]

58. Yan, W.; Banerjee, P.; Liu, Y.; Mi, Z.; Bai, C.; Hu, H.; To, K.W.K.; Duong, H.T.T.; Sy Leung, S. Development of Thermosensitive Hydrogel Wound Dressing Containing Acinetobacter Baumannii Phage against Wound Infections. Int. J. Pharm. 2021, 120508. [CrossRef]

59. Thanki, A.M.; Brown, N.; Millard, A.D.; Clokie, M.R.J. Genomic Characterization of Jumbo Salmonella Phages That Effectively Target United Kingdom Pig-Associated Salmonella Serotypes. Front. Microbiol. 2019, 10, 1491. [CrossRef]

60. Tsourkas, P.K. Paenibacillus Larvae Bacteriophages: Obscure Past, Promising Future. Microb. Genom. 2020, 6. [CrossRef]

61. Jia, K.; Yang, N.; Zhang, X.; Cai, R.; Zhang, Y.; Tian, J.; Raza, S.H.A.; Kang, Y.; Qian, A.; Li, Y.; et al. Genomic, Morphological and Functional Characterization of Virulent Bacteriophage IME-JL8 Targeting Citrobacter Freundii. Front. Microbiol. 2020, $11,585261$. [CrossRef] [PubMed]

62. Nikapitiya, C. Isolation and Characterization of Phage (ETP-1) Specific to Multidrug Resistant Pathogenic Edwardsiella Tarda and Its in Vivo Biocontrol Efficacy in Zebrafish (Danio Rerio). Biologicals 2020, 63, 14-23. [CrossRef] 
63. Khairnar, K.; Raut, M.P.; Chandekar, R.H.; Sanmukh, S.G.; Paunikar, W.N. Novel Bacteriophage Therapy for Controlling Metallo-Beta-Lactamase Producing Pseudomonas Aeruginosa Infection in Catfish. BMC Vet. Res. 2013, 9, 264. [CrossRef] [PubMed]

64. Hoang, A.H.; Tran, T.T.X.; Le, P.N.; Dang, T.H.O. Selection of Phages to Control Aeromonas Hydrophila-An Infectious Agent in Striped Catfish. Biocontrol Sci. 2019, 24, 23-28. [CrossRef] [PubMed]

65. Le, T.S.; Southgate, P.C.; O'Connor, W.; Vu, S.V.; Kurtböke, D.İ. Application of Bacteriophages to Control Vibrio Alginolyticus Contamination in Oyster (Saccostrea Glomerata) Larvae. Antibiotics 2020, 9, 415. [CrossRef]

66. Le, T.S.; Southgate, P.C.; O'Connor, W.; Abramov, T.; Shelley, D.; Vu, S.V.; Kurtböke, D.İ. Use of Bacteriophages to Control Vibrio Contamination of Microalgae Used as a Food Source for Oyster Larvae during Hatchery Culture. Curr. Microbiol. 2020, 77, 1811-1820. [CrossRef]

67. Srinivasan, R.; Chaitanyakumar, A.; Subramanian, P.; Mageswari, A.; Gomathi, A.; Aswini, V.; Sankar, A.M.; Ramya, M.; Gothandam, K.M. Recombinant Engineered Phage-Derived Enzybiotic in Pichia Pastoris X-33 as Whole Cell Biocatalyst for Effective Biocontrol of Vibrio Parahaemolyticus in Aquaculture. Int. J. Biol. Macromol. 2020, 154, 1576-1585. [CrossRef]

68. Silva, Y.J.; Costa, L.; Pereira, C.; Mateus, C.; Cunha, Â.; Calado, R.; Gomes, N.C.M.; Pardo, M.A.; Hernandez, I.; Almeida, A. Phage Therapy as an Approach to Prevent Vibrio Anguillarum Infections in Fish Larvae Production. PLoS ONE 2014, 9 , e114197. [CrossRef]

69. Richards, G.P.; Watson, M.A.; Madison, D.; Soffer, N.; Needleman, D.S.; Soroka, D.S.; Uknalis, J.; Baranzoni, G.M.; Church, K.M.; Polson, S.W.; et al. Bacteriophages against Vibrio Coralliilyticus and Vibrio Tubiashii: Isolation, Characterization and Remediation of Larval Oyster Mortalities. Appl. Environ. Microbiol. 2021. [CrossRef]

70. Brady, T.S.; Merrill, B.D.; Hilton, J.A.; Payne, A.M.; Stephenson, M.B.; Hope, S. Bacteriophages as an Alternative to Conventional Antibiotic Use for the Prevention or Treatment of Paenibacillus Larvae in Honeybee Hives. J. Invertebr. Pathol. 2017, 150, 94-100. [CrossRef]

71. Carstens, A.B.; Djurhuus, A.M.; Kot, W.; Hansen, L.H. A Novel Six-Phage Cocktail Reduces Pectobacterium Atrosepticum Soft Rot Infection in Potato Tubers under Simulated Storage Conditions. FEMS Microbiol. Lett. 2019, 366, fnz101. [CrossRef]

72. Buttimer, C.; Hendrix, H.; Lucid, A.; Neve, H.; Noben, J.-P.; Franz, C.; O’Mahony, J.; Lavigne, R.; Coffey, A. Novel N4-Like Bacteriophages of Pectobacterium Atrosepticum. Pharmaceuticals 2018, 11, 45. [CrossRef] [PubMed]

73. Zaczek-Moczydłowska, M.A.; Young, G.K.; Trudgett, J.; Plahe, C.; Fleming, C.C.; Campbell, K.; O’ Hanlon, R. Phage Cocktail Containing Podoviridae and Myoviridae Bacteriophages Inhibits the Growth of Pectobacterium spp. under in Vitro and in Vivo Conditions. PLoS ONE 2020, 15, e0230842. [CrossRef]

74. Marei, E.M.; El-Afifi, S.I.; Hammad, A.M. Biochemical and Molecular Characteristics of Pc1 Virulent Phage Isolate Infecting Pectobacterium Carotovorum. Pak. J. Biol. Sci. 2020, 23, 1481-1486. [CrossRef]

75. Ashfield-Crook, N.R.; Woodward, Z.; Soust, M.; Kurtböke, D.İ. Bioactive Streptomycetes from isolation to applications: A Tasmanian potato farm example. In The Plant Microbiome; Carvalhais, L.C., Dennis, P.G., Eds.; Methods in Molecular Biology; Springer US: New York, NY, USA, 2021; Volume 2232, pp. 219-249, ISBN 978-1-07-161039-8.

76. Carstens, A.; Djurhuus, A.; Kot, W.; Jacobs-Sera, D.; Hatfull, G.; Hansen, L. Unlocking the Potential of 46 New Bacteriophages for Biocontrol of Dickeya Solani. Viruses 2018, 10, 621. [CrossRef]

77. Adriaenssens, E.M.; Van Vaerenbergh, J.; Vandenheuvel, D.; Dunon, V.; Ceyssens, P.-J.; De Proft, M.; Kropinski, A.M.; Noben, J.-P.; Maes, M.; Lavigne, R. T4-Related Bacteriophage LIMEstone Isolates for the Control of Soft Rot on Potato Caused by Dickeya Solani. PLoS ONE 2012, 7, e33227. [CrossRef] [PubMed]

78. Wei, C.; Liu, J.; Maina, A.N.; Mwaura, F.B.; Yu, J.; Yan, C.; Zhang, R.; Wei, H. Developing a Bacteriophage Cocktail for Biocontrol of Potato Bacterial Wilt. Virol. Sin. 2017, 32, 476-484. [CrossRef] [PubMed]

79. Bae, J.Y. Biocontrol Potential of a Lytic Bacteriophage PE204 against Bacterial Wilt of Tomato. J. Microbiol. Biotechnol. 2012, 22, 1613-1620. [CrossRef] [PubMed]

80. Álvarez, B.; López, M.M.; Biosca, E.G. Biocontrol of the Major Plant Pathogen Ralstonia Solanacearum in Irrigation Water and Host Plants by Novel Waterborne Lytic Bacteriophages. Front. Microbiol. 2019, 10, 2813. [CrossRef]

81. Wang, X.; Wei, Z.; Yang, K.; Wang, J.; Jousset, A.; Xu, Y.; Shen, Q.; Friman, V.-P. Phage Combination Therapies for Bacterial Wilt Disease in Tomato. Nat. Biotechnol. 2019, 37, 1513-1520. [CrossRef]

82. Hernandez, C.A.; Salazar, A.J.; Koskella, B. Bacteriophage-Mediated Reduction of Bacterial Speck on Tomato Seedlings. PHAGE 2020, 1, 205-212. [CrossRef] [PubMed]

83. Rabiey, M.; Roy, S.R.; Holtappels, D.; Franceschetti, L.; Quilty, B.J.; Creeth, R.; Sundin, G.W.; Wagemans, J.; Lavigne, R.; Jackson, R.W. Phage Biocontrol to Combat Pseudomonas Syringae Pathogens Causing Disease in Cherry. Microb. Biotechnol. 2020, 13, 1428-1445. [CrossRef]

84. Zaczek-Moczydłowska, M.A.; Young, G.K.; Trudgett, J.; Fleming, C.C.; Campbell, K.; O’Hanlon, R. Genomic Characterization, Formulation and Efficacy in Planta of a Siphoviridae and Podoviridae Protection Cocktail against the Bacterial Plant Pathogens Pectobacterium spp. Viruses 2020, 12, 150. [CrossRef] [PubMed]

85. Lorito, M.; Capparelli, R. Plant Dynamic Metabolic Response to Bacteriophage Treatment after Xanthomonas Campestris Pv Campestris Infection. Front. Microbiol. 2020, 11, 15.

86. Rahimi-Midani, A.; Choi, T.-J. Transport of Phage in Melon Plants and Inhibition of Progression of Bacterial Fruit Blotch. Viruses 2020, 12, 477. [CrossRef] [PubMed]

87. Tuson, H.H.; Weibel, D.B. Bacteria-Surface Interactions. Soft Matter 2013, 9, 4368. [CrossRef] [PubMed] 
88. Fryer, P.J.; Asteriadou, K. A Prototype Cleaning Map: A Classification of Industrial Cleaning Processes. Trends Food Sci. Technol. 2009, 20, 255-262. [CrossRef]

89. Busscher, H.J.; Norde, W.; van der Mei, H.C. Specific Molecular Recognition and Nonspecific Contributions to Bacterial Interaction Forces. Appl. Environ. Microbiol. 2008, 74, 2559-2564. [CrossRef]

90. Jain, S.; Chen, J. Attachment and Biofilm Formation by Various Serotypes of Salmonella as Influenced by Cellulose Production and Thin Aggregative Fimbriae Biosynthesis. J. Food Prot. 2007, 70, 2473-2479. [CrossRef] [PubMed]

91. Islam, M.S.; Zhou, Y.; Liang, L.; Nime, I.; Liu, K.; Yan, T.; Wang, X.; Li, J. Application of a Phage Cocktail for Control of Salmonella in Foods and Reducing Biofilms. Viruses 2019, 11, 841. [CrossRef]

92. Sadekuzzaman, M.; Mizan, M.F.R.; Yang, S.; Kim, H.-S.; Ha, S.-D. Application of Bacteriophages for the Inactivation of Salmonella Spp. in Biofilms. Food Sci. Technol. Int. 2018, 24, 424-433. [CrossRef] [PubMed]

93. Gong, C.; Jiang, X.; Wang, J. Application of Bacteriophages to Reduce Salmonella Contamination on Workers' Boots in RenderingProcessing Environment. Poult. Sci. 2017, 96, 3700-3708. [CrossRef]

94. Zhang, Y.; Hu, Z. Combined Treatment of Pseudomonas Aeruginosa Biofilms with Bacteriophages and Chlorine. Biotechnol. Bioeng. 2013, 110, 286-295. [CrossRef] [PubMed]

95. Møretrø, T.; Langsrud, S. Residential Bacteria on Surfaces in the Food Industry and Their Implications for Food Safety and Quality: Residential Bacteria in Food Industry. Compr. Rev. Food Sci. Food Saf. 2017, 16, 1022-1041. [CrossRef]

96. Magin, V.; Garrec, N.; Andrés, Y. Selection of Bacteriophages to Control in Vitro 24 h Old Biofilm of Pseudomonas Aeruginosa Isolated from Drinking and Thermal Water. Viruses 2019, 11, 749. [CrossRef]

97. Wang, C.; Hang, H.; Zhou, S.; Niu, Y.D.; Du, H.; Stanford, K.; McAllister, T.A. Bacteriophage Biocontrol of Shiga Toxigenic Escherichia Coli(STEC) O145 Biofilms on Stainless Steel Reduces the Contamination of Beef. Food Microbiol. 2020, $92,103572$. [CrossRef]

98. Mukherjee, A.K.; Bhagowati, P.; Biswa, B.B.; Chanda, A.; Kalita, B. A Comparative Intracellular Proteomic Profiling of Pseudomonas Aeruginosa Strain ASP-53 Grown on Pyrene or Glucose as Sole Source of Carbon and Identification of Some Key Enzymes of Pyrene Biodegradation Pathway. J. Proteom. 2017, 167, 25-35. [CrossRef]

99. Lee, E.-H.; Cho, K.-S. Characterization of Cyclohexane and Hexane Degradation by Rhodococcus Sp. EC1. Chemosphere 2008, 71, 1738-1744. [CrossRef]

100. Tremblay, J.; Yergeau, E.; Fortin, N.; Cobanli, S.; Elias, M.; King, T.L.; Lee, K.; Greer, C.W. Chemical Dispersants Enhance the Activity of Oil- and Gas Condensate-Degrading Marine Bacteria. ISME J. 2017, 11, 2793-2808. [CrossRef]

101. Pomeroy, L.R.; Williams, P.J.1.B.; Azam, F.; Hobbie, J.E. The Microbial Loop. Oceanography 2007, 20, 28-33. [CrossRef]

102. Rosenberg, E.; Bittan-Banin, G.; Sharon, G.; Shon, A.; Hershko, G.; Levy, I.; Ron, E.Z. The Phage-Driven Microbial Loop in Petroleum Bioremediation. Microb. Biotechnol. 2010, 3, 467-472. [CrossRef]

103. Bratbak, G.; Thingstad, F.; Heldal, M. Viruses and the Microbial Loop. Microb. Ecol. 1994, 28, 209-221. [CrossRef] [PubMed]

104. Khairnar, K.; Chandekar, R.; Nair, A.; Pal, P.; Paunikar, W.N. Novel Application of Bacteriophage for Controlling Foaming in Wastewater Treatment Plant- an Eco-Friendly Approach. Bioengineered 2016, 7, 46-49. [CrossRef] [PubMed]

105. Choi, J.; Kotay, S.M.; Goel, R. Bacteriophage-Based Biocontrol of Biological Sludge Bulking in Wastewater. Bioeng. Bugs 2011, 2, 214-217. [CrossRef]

106. Colavecchio, A.; Goodridge, L.D. Phage Therapy Approaches to Reducing Pathogen Persistence and Transmission in Animal Production Environments: Opportunities and Challenges. Microbiol. Spectr. 2017, 5. [CrossRef]

107. Colomer-Lluch, M.; Jofre, J.; Muniesa, M. Quinolone Resistance Genes (QnrA and QnrS) in Bacteriophage Particles from Wastewater Samples and the Effect of Inducing Agents on Packaged Antibiotic Resistance Genes. J. Antimicrob. Chemother. 2014, 69, 1265-1274. [CrossRef] [PubMed]

108. Boling, L.; Cuevas, D.A.; Grasis, J.A.; Kang, H.S.; Knowles, B.; Levi, K.; Maughan, H.; McNair, K.; Rojas, M.I.; Sanchez, S.E.; et al. Dietary Prophage Inducers and Antimicrobials: Toward Landscaping the Human Gut Microbiome. Gut Microbes 2020, 11, 721-734. [CrossRef] 